\title{
Global Shared Service Trends in the Central and Eastern European Markets
}

\author{
Róbert Marciniak
}

\begin{abstract}
A B S T R A C T
Objective: To disclose what kind of trends are present in the global business service markets and which appear in the Central and Eastern European (CEE) business market.

Research Design \& Methods: The research is based on both a literature review and empirical studies. The first part of the empirical research consisted of a series of interviews with qualitative data, the second part was a questionnaire study with mostly quantitative data. The interview research results are based on 12 interviews. The interviewees were business consultants, HR agency leaders, representatives of governmental agencies, professional non-profit organizations, and an academic researcher. questionnaire study is based on the respondents of 51 shared service centers in Hungary.
\end{abstract}

Findings: The development of the shared service sector plays an increasingly important role in the growth of the national economies in CEE region. In the CEE region the salary level, geographical proximity, cultural homogeneity and the development of infrastructure attract investor companies. Shared service centers (SSCs) provide a range of business services - most notably in the areas of finance, accounting, procurement, logistics, information technology and human resources mostly regionally and sometimes globally.

Implications \& Recommendations: The identified trends are limited to the shared service organizations (SSO) operating in the private sector in the CEE business service market.

Contribution \& Value Added: The research determines the most important business service trends that emerged in shared service organizations in the CEE region.

\begin{tabular}{llll}
\hline Article type: & $\begin{array}{l}\text { research paper } \\
\text { Keywords: }\end{array}$ & $\begin{array}{l}\text { Shared Service } \\
\text { business services; Central and Eastern Europe (CEE) }\end{array}$ & \\
JEL codes: & M16, M19 & & \\
\hline Received: 15 February 2014 & Revised: 2 April 2014 & Accepted: 16 June 2014 \\
\hline
\end{tabular}

\section{Suggested citation:}

Marciniak, R. (2014). Global Shared Service Trends in the Central and Eastern European Markets. Entrepreneurial Business and Economics Review, 2(3), 63-78. 


\section{INTRODUCTION}

Over the last decade, there has been rapid growth in the business service industry in Central and Eastern European (CEE) countries. Nowadays, this region plays a very important role in the global business service market (Shared Services Centers, SSC or much wider as Business Process Outsourcing, BPO). Within the business service industry, the shared service sector has outgrown itself and has become one of the key segments in this service industry.

The growth of the shared service market rearranged the whole labor market in these countries and in the last decade it has become one of the most significant employers. The shared service sector is very popular in CEE countries among recent graduates with foreign language knowledge because it provides quite high salaries, an international work environment, and a modern and young work culture.

However, the shared service market is continuously developing. There are newer and newer global trends influencing it. Understanding the trends and exploiting their advantages could be the source of survival and progress for the market. The research is to disclose what kind of trends are present in the global business service markets and which appear in the CEE business market.

\section{LITERATURE REVIEW}

\section{Popularity of the CEE Region on the Global Service Market}

The shared services (SS) model was launched in the USA in the 1980s, however, much time passed before its international expansion and it appeared in Europe only in the early 1990s, first in the Nordic region and Great Britan, the Iberian Peninsula and the Netherlands. The first shared service centers in Central and Eastern Europe (CEE) were developed later, in the late 1990s. However, after they discovered the region, the number of new service centers began to grow dynamically.

In the early 2000s, 91 service centers were established in the CEE region on the basis of the UNCTAD data, with nearly one-third of them, 26, established in Hungary (Chikán \& Petényi, 2009).

The reasons for the popularity of the region in the early 2000s are complex. One reason is, of course, the attractive economic environment, including the favorable tax regime and available labor advantages due to lower salaries. The labor advantages differ depending on the service areas, but nowadays it is about $30-40 \%$ lower compared with the level of Western Europe. Another advantage is the language proficiency (such services required a wide range of European and global languages). As long as North American companies and their partners are mostly use English language and most of the service centers were taken to India, many large European companies and several global companies have multilingual customer and partner base, so it was important to them to establish shared service centers in advanced European countries from where they can serve the multilingual clientele. For this purpose the CEE region is perfect.

Monika Pinter, who was previously the CEE SSC Head of PwC's consulting firm in Hungary and now works as a partner at DLM Consulting Group, argued that one of the 
main reasons that American and Western European companies began to establish shared service organizations in the early 2000s was that this was exactly the time when these business markets began to globalize, which brought a variety of nearshoring and offshoring solutions (Pintér, 2012).
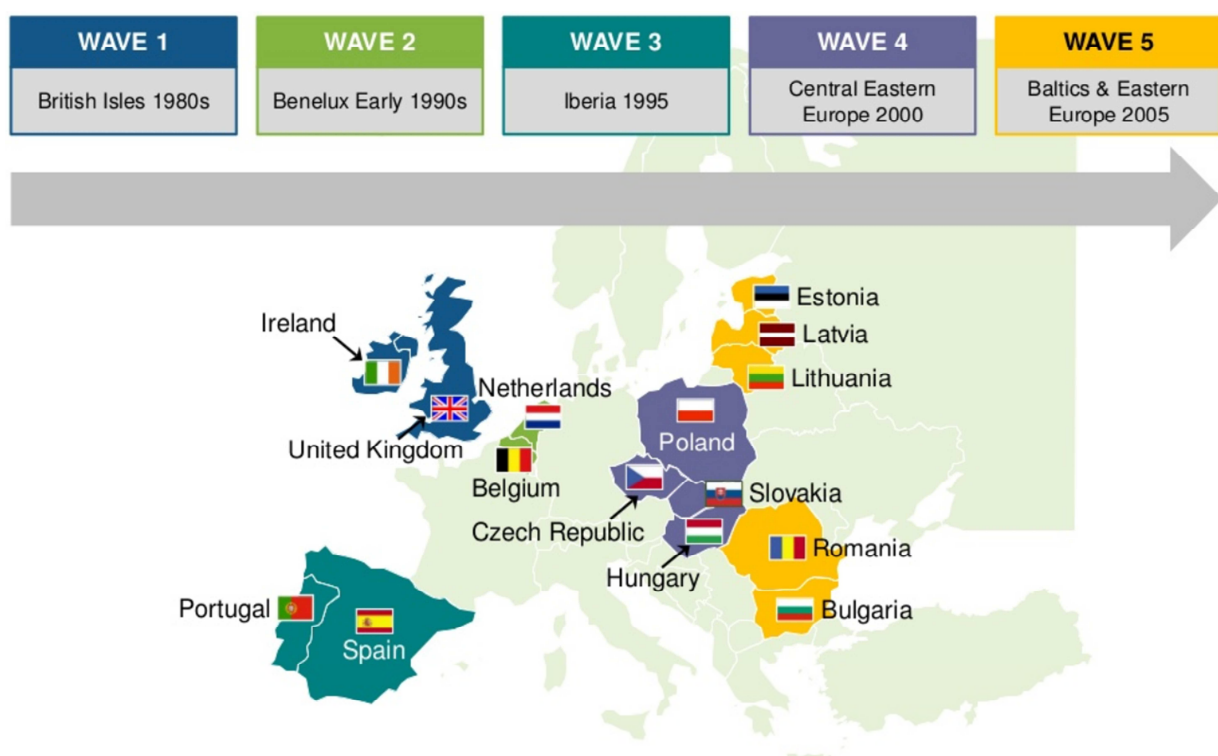

Figure 1. European Expansion of the Shared Service Model

Source: (Bangemann, 2012, p. 16)

The expansion is still ongoing, and it is proven that up until 2006, 183 shared service centers had been established in Central and Eastern Europe countries, which are one of the most important nearshore locations for Western Europe.

In addition to the advantages of these countries, NATO and European Union membership could also play significant role. Until the CEE countries' accession to the EU in 2004, multinational companies managed Western Europe and Central and Eastern Europe as different markets. They had to relocate their standardizable functions from Western European centers to the new member countries. Since the latter has become more realizable cost benefits, and it was simpler to find and use Eastern European workers, who speak Western European languages than the other way, many Western companies set up a service center in the CEE region.

Another factor that could have played a role in the huge interest surrounding the CEE region countries was that global companies perceived that they could not deliver business services globally from one geographical location, e.g. from India, which has the highest cost-advantage. Global companies recognized at that time that if they wanted to work globally, they would needs service centers operating $24 / 7$. To do this, it was not enough to establish a service center in the U.S. and/or in India, one or more were also needed in the countries of Central and Eastern Europe (Bencsik, 2012). These companies began building service delivery networks to cover their clientele in all time zones 
throughout the world. The significant location of the CEE region in terms of time zones is very beneficial because these centers can serve America in the afternoon and evening hours, Asia in the early morning, but also in the case of the entire Europe, Middle East and Africa - but with a minimum difference. The region is not only very well located geographically, but it also has a developed office and IT infrastructure and a trained labor force with proficiency in many foreign languages, which is relatively cheap compared with that of Western European countries. This advantage is true mainly in Poland, the Czech Republic and Hungary, which is the reason why these countries have become the most important SSC markets in Central and Eastern Europe.

\section{MATERIAL AND METHODS}

The interview method was used to get an overall picture with the help of CEE business service market experts. The questionnaire method helped analyze these global trends in practice. In this analysis, the pilot country was Hungary.

Both research analyses were based not on a longitudinal, but a cross-sectional study. The interviewees composed their statements based on their knowledge about the last decades (2004-2013).

In the first part of the primary research consisted of a series of interviews meant to reveal market characteristics and identify market problems. Particular attention was paid to determining the research sample. The experts chosen have an unbiased approach to the trends on the global and CEE service market. These interviewees were chosen not from service centers but from research institutes, academics, consulting firms, and professional and governmental agencies. There was evidence in the literature that these interviewees have adequate knowledge about the market. Initially, eight professionals were chosen as interviewees, but snowball sampling helped recruit new interviewees. Thanks to this research technique, 12 semi-structured interviews were conducted (Appendix). Eight of these interviews were conducted face-to-face, four were conducted by phone. The interviews lasted about 45 minutes and were recorded by digital voice recorder. All interviews were conducted in 2013.

In the second part of the study, global trends on Hungarian shared service organizations were tested. First, 77 separate companies were identified that had at least one shared service center in Hungary at time of the study. The database was combined based on different databases of professional organizations and own collecting. All Hungarian shared service centers were contacted. The response was voluntary, and all centers had the chance to respond. The centers were contacted electronically or by phone, and the data was collected in an online, self-fill-in survey in every case. 51 of the 84 shared service centers filled out the questionnaire, making the response rate $61 \%$.

\section{RESULTS AND DISCUSSION}

\section{Position of the CEE Region in the Global Service Market}

Currently, the list of global service locations is relatively short. Although this list is constantly changing, some countries have reached very good positions for themselves and have a matured service market, which is popular for service companies planning to 
invest abroad. Ten years ago, most of the service FDI was focused on the most developed countries, but now the focus has shifted to developing countries and semideveloped countries like those in the CEE region.

In the global list, India, China and Malaysia have been ranked on the top three places since the first measurement in 2004 (the countries of the CEE region are not in the first positions). However, if we examine the level of the region, but not the particular countries, Central and Eastern Europe is the third most attractive investment location (Lhermitte et al., 2010). With regard to location, it seems that no one is in a position to threaten India's position for the time being, since India built a good service infrastructure early (which was supported), and the labor cost is still only a quarter of what it is in Western European countries and about half of what it is in Eastern European countries. Against India, besides the geographical proximity to both Western Europe and the Middle East, another advantage of the CEE countries is its labor force's proficiency in the major world languages and its time zone overlapping with U.S. business time.

Countries in the CEE region have begun competing with one another to attract service center investments to the CEE region. These countries, or even specific regions, have made very attractive offers, incentives and created strategies for the industry and framework designed to help attract and retain investments.

The Central and Eastern European countries are in the global rankings. Although in the past five years Hungary, the Czech Republic, Poland, and Slovakia did not place in the top twenty, the size of the business service sector in these countries continues to increase. However, the position of the Baltic countries (Estonia, Latvia, Lithuania) strengthened significantly, and greatly improved the way Romania and Bulgaria are perceived as well.

In the global services market, there are many countries ahead of the CEE countries, but there is no point in treating India as a competitor because the companies move primarily those mass production-type services that do not require specific skills. Central and Eastern European countries lost their ground in the global services market mainly due to the rising costs and the Middle East and countries in North Africa have appeared among the best locations. However, the position of North Africa was temporarily shaken by the 2011 anti-government demonstrations called "Arab Spring," which caused social and economic turmoil in a number of MENA (Middle-East and North Africa) countries and its impact (e.g. Syria) is still felt.

Compared with Far Eastern service centers, the benefits of the CEE region are that European companies demand that such shared service centers, which operate at the same European linguistic and cultural background, have good local contacts and are easily accessible. The Central and Eastern European region have advanced IT and telecommunications infrastructure and its labor market offers highly qualified, German and English speaking professionals. Nearshore activities allow companies to respond quickly due to the lack of time zone difference and lack of language barriers (Mózsik, 2008). Companies prefer nearshoring to the great cost benefits of offshoring due to the cultural, geographic and linguistic similarities nearshoring provides.

Based on the new SSC jobs created in recent years, Asian cities have a very strong position, but there are thirteen European cities with the best twenty, like Bucharest, Budapest and Prague. 
For the time being, Europe holds a stable and balanced position in the global service sector. Stable, because the number of new jobs has not decreased since 2011, and balanced, because the SSC jobs are divided almost evenly between Western Europe and Central and Eastern Europe. Romania occupies a very good position, with ClujNapoca and Bucharest in the top twenty cities in a global ranking of SSC sites. Serbia and Turkey were the two most promising countries in Europe in 2011 (van Hove, 2011). Because of the length of the crisis in the region, the competition between Hungary, the Czech Republic, Poland, Romania and Bulgaria is likely to increase.

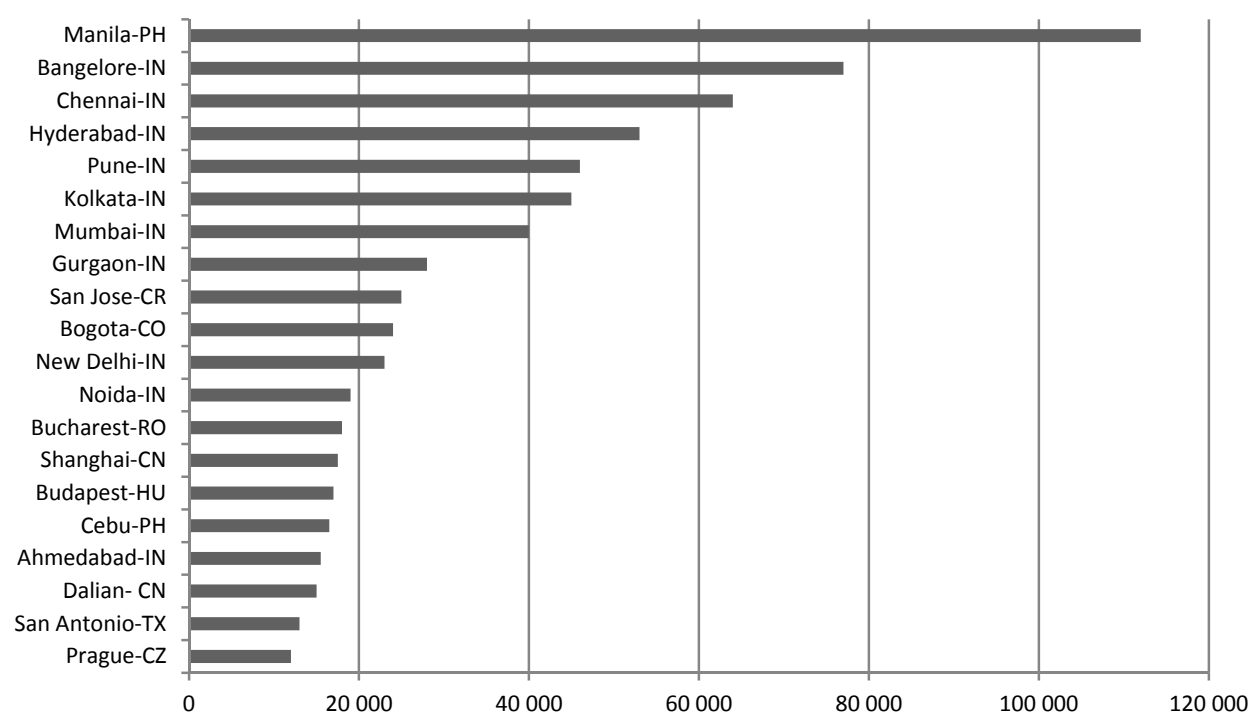

Figure 2. Global ranking of SSC cities Source: (van Hove, 2011, p. 3).

\section{Global Trends for Shared Service Centers}

There are more global trends in the business service market. These trends show the strategic, structural solutions of those organizations that are using these sourcing models in the near and the far future well. These trends affect the CEE market as well. It was analyzed how these trends affect the players in the regional shared service market.

\section{Service delivery trends}

One of these trends is the centralization of technology and service delivery that was in the focus in recent years. Centralization does not mean that one function should be delivered from one location. Moreover, technological progress makes this less and less necessary. But it is expected that all functions will be controlled and changed by the same principles. The integration of offshoring, outsourcing and shared service models is another strong trend (A.T. Kearney, 2004).

Examination of these shared service centers has shown that the majority of them are multi-functional centers. Only $14 \%$ of the respondent centers were single-function. The average number of services encompass 4.5 areas, but their activities very often vary. 
The presence of value-added services was also analyzed. $60.5 \%$ of respondents argued that in their service portfolio there is a fifty-fifty ratio between higher transactions and value-added services.

Another trend is the widening of shared service centers' service portfolios. Today, more than half of the active centers perform more than one service activity. There is steady growth in the use of transactional pricing. The centers in charge of shared service functions use transactional pricing instead of FTE-based allocation. This means that the service price is determined by the number of transactions (Sangani, 2011).

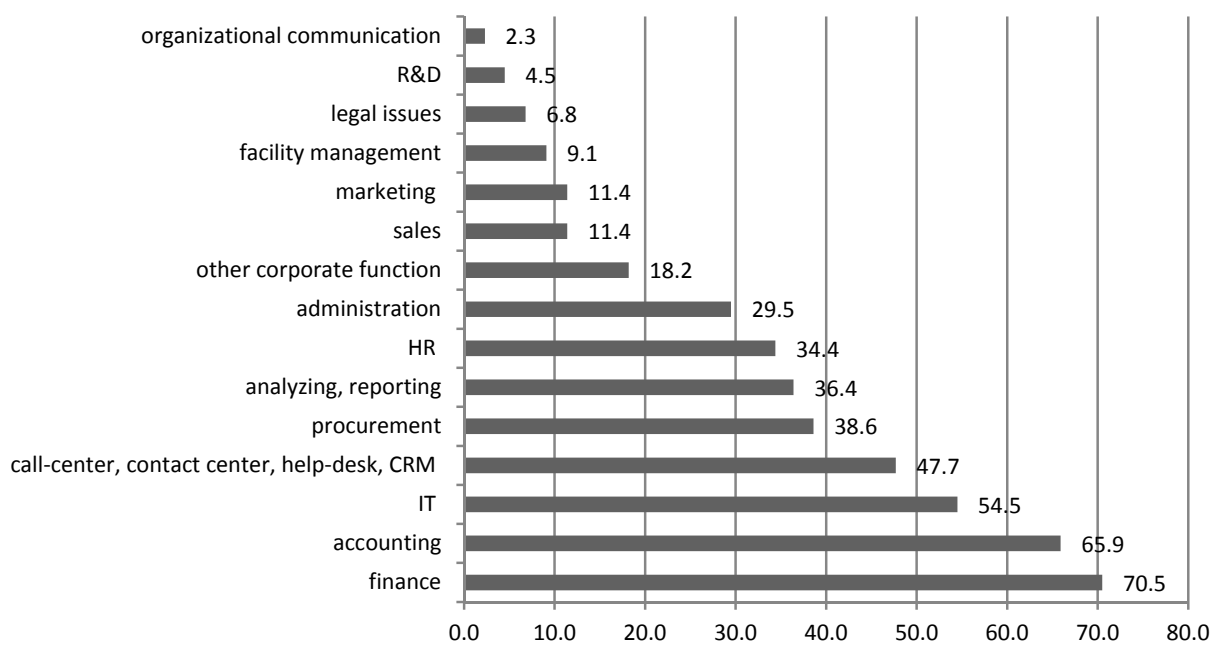

Figure 3. Service portfolio of SSC respondents (in \%)

Source: own study based the questionnaire survey among Hungarian SSCs.

The respondent service centers had a mostly international client base. $44 \%$ of them provide services to 16 to 18 or more countries and $59.5 \%$ of them to 18 or more countries per service. $70.5 \%$ of the investigated shared service centers provide services only to departments of the parent company, and so, lacking external customers, use the captive center model. Those centers which also had external clients have a large number of clients to serve. $81.8 \%$ of the respondents had at least 10 external customers. The parent companies of $58.3 \%$ of these centers had other partnerships with the external clients as well.

$81 \%$ of respondents have changed their service portfolio since its inception. $97.1 \%$ of these centers have gained new features, but claimed that only $2.9 \%$ of them were quality changes replacing a lower value-added service with a higher one. The future growth of the market was anticipated by service center leaders. Half of them were planning to expand their service portfolios with new services. Based on the research, this expansion will be significant mostly in the areas of $\mathrm{HR}$, analysis and reporting, procurement, finance and service. 


\section{Organizational trends}

From a geographical perspective, successful shared service centers are changing their focus from the regional service center model to the hub-and-spoke model. As global working and service delivery became possible, , parent companies began establishing their service centers in the most organizationally and financially optimal locations. This is the reason behind the growing number of greenfield investments in the area of shared services. According to Accenture consulting firm, $20-30 \%$ of new shared service investment are greenfield. In terms of operating models, multi-functional shared service centers are very fashionable. In such centers, two or more functions are under the control of the same manager, delivered by the same service model and structurally organized in the same way. According to the research done by Accenture, the multifunctional model prevails today. The question could be posed whether the multifunctional model is preferable to the one-functional centre. According to Accenture's research, company executives confirmed that the benefits available through the implementation of multi-functional centers could be even greater than expected (London, 2008).

$59 \%$ of respondents that have more shared service centers within the parent organization use the hub-and-spoke model. Certain divisions in service delivery exist and in this cooperation Hungary is the hub in most cases.

\section{Appearance of the hybrid model}

Over the last decade, both outsourcing and the shared service approach have evolved considerably, but in case any of the exclusive choice, companies must constantly balance evaluating advantages and disadvantages of these models, and usually always have to make a compromise. There are many examples of such a dilemma: cost reduction versus a loss of control over the resources, outsourcing versus retention of non-core activities, rule-based processes versus customized processes.

To solve these dilemmas, the leading companies frequently use hybrid models when combining back-office outsourcing with captive centers under tight cooperation.

The hybrid model may implement rightshoring when companies move some services (e.g., front-office) to onshore or nearshore locations that are close in space and time and culturally-similar (such as in Central and Eastern Europe), and back-office services to cheaper, geographically and culturally distant countries (e.g. India, China, South Africa). The first case is implemented by the shared service center itself, while the latter is achieved through an outsourcing partner (Williams, 2005).

The research confirmed that $54 \%$ of respondents use a hybrid model that combines the shared service model with outsourcing. Among these hybrid solutions, the most common (44\%) is the virtual captive model, followed by BOT or BOOT (22\%), while $25 \%$ of respondents use other hybrid solutions.

In the study, only $14 \%$ of respondent companies said that there is no virtualization of their organizational operations. 


\section{Models for operational excellence}

According to Hackett Group's 2012 study, 80\% of the best performing companies are preparing for the introduction of knowledge-intensive services to their global provider organization. $70 \%$ of companies are planning to expand the service portfolios of their service centers. $72 \%$ of companies are already using multi-functional service centers and the rate is expected to increase in the future. The best-performing companies provide $63 \%$ of all financial activities from a service center. Similarly, $54 \%$ of companies carry out all purchasing activities from a service center (Hackett Group, 2012).

The future belongs to integrated business service providers. These are independent organizations that provide a wide range of services at a high level of accountability, as well asend-to-end services. These service providers will break in those pioneering new service areas, which today are still outside the scope of the centers, such as promotions management, research and planning, or customer analysis. Integrated business services performed usually by back-offices or SSCs are getting closer to front-office activities and so a much more diverse shared services model is created (Boulanger, 2011).

According to Accenture's 2004 survey, the shared service model is becoming less concentrated on transaction-based processing back-office functions and developing in the direction of the Centers of Excellence (CoE) model (Sutcliff, 2004).

Over the past three to five years, significant changes have occurred in shared service organizations. Using new tools and an enhanced corporate image, they have transformed into global business service providers. Their name is telling because they operate in a global environment that exploits both the geographical and labor benefits available. They provide more services that are better integrated with the business of the company. The service orientation is towards the cross-culture and performance optimization, which was missing in the earlier shared service model.

Today, the focus has shifted from classical outsourcing to business process outsourcing in this region. Shared service organizations are being transformed into global business service providers (Global Business Services, GBS) with new tools and a new design. More and more companies are moving from the operations of traditional SSCS towards becoming global business service companies. This indicates that the companies see shared service centers as a strategic factor. This way of thinking made the full strategic control of all processes, the move from functional processes to end-to-end processes and the uniform representation of the business unit's management possible. Global business services were created as an independent legal entity in order to strengthen the corporate trend that SSC will have real service and process-oriented culture and a unique company character. The price of human resources increases as the firms begin to use primarily nearshore locations like Central and Eastern Europe (CEE), and this solution brings higher value-added services rather than transactional advantages.

The study confirmed that market-based service centers are constantly expanding and developing. Most of the respondent centers asserted that they are continuously progressing, visible most notably in the number of people hired by the firm and in the widening of its scope and liability. In addition, the respondents have identified two directions in service center development: the Centers of Excellence (CoE) and the Global Business Services (GBS) organization solutions. 
In the study, one third of the shared service centers were in the organization structure as a division, while $35.7 \%$ of them were within a division and $31 \%$ functioned as independent centers assigned to the central headquarters. Some service centers operate as independent subsidiaries, others have more centers at different sites and others at one company site operated more service centers.

At $51.2 \%$ of the shared service centers, the company headquarters makes decisions about the services provided, in $17.2 \%$ of these centers decisions are made in the regional center (hub), and in $29.3 \%$ of them decisions are made by the division. Only $2.4 \%$ of these service centers have decision-making authority. The service centers do not have decisional authority in choosing clients (internal-external), this matter is always decided on a higher level.

The networking of service centers showed that $45.2 \%$ of the centers purchase services from other service centers within the parent company or from external service providers. This issue is also centralized, on the top management level in headquarters. For $44 \%$ of them the global center makes decisions about the services purchased, for $12 \%$ of them it is the regional headquarters that decides, and for another $44 \%$, the division has the decision-making authority regarding services purchased. The centralization of decision-making highlighted the research result that at $72.1 \%$ of the companies, the departments of the parent company could not buy services from another provider, but only from the internal shared service center, $16.3 \%$ of them are competitors among the internal service centers for service delivering, and $11.6 \%$ had the chance to buy from an external service provider as well.

\section{Human labor in the service centers}

'Body shopping' is the nickname for the migration of services into shared service centers from cheaper countries. This is so usually in the Far East, but not in the CEE countries, where 'head shopping' is typical instead. While it is common for services with less responsibility to migrate e.g. in India, in Hungary the headquarters and research centers are more important (Figyelö, 2009).

Although most of the shared service centers advertise themselves as the starting points of international careers, according to Hoffmann (2002) there are relatively few employees who can go from a domestic subsidiary to the headquarters within the company. More prevalent in the sector is the 'job-hopping' phenomenon when an employee changes jobs not vertically, but horizontally, i.e. he/she changes companies and not positions for a higher salary (sometimes the difference is $20,000-30,000$ HUF per month).

In service centers, the most important requirements for young graduates are the ability to learn quickly and to make decisions quickly. In making a decision the employee's main task is to determine whether they are being faced with a standard process or not. If they are, then it must be handled on the basis of the standard knowledge base, but if not, then the employee has to pass the process on to another colleague who has the authority to handle it.

The majority of workers recruited in service centers are between 25-35 years old and have at least a bachelor's degree. A relatively large number of foreigners work in these centers, so a multi-cultural environment is typical in these centers, which is why 
they are recommended only for employees who are open to diversity and use foreign languages on a daily basis.

In the service centers, there is higher employee turnover than in other sectors. This is mostly because the requirements for employees can be met only by those with a higher education. The work in these centers may be very interesting at first, but after a while it may become monotonous and the workers with foreign language proficiency change jobs. Actually, the more successful the centers are (the more standardized the centre are), the more monotonous the work is for the employees. This is contrary to the expectations of newly graduated, well-trained young people, and they will therefore change jobs. It is common for them to move to other service centers to receive higher positions (SSC Recruitment, 2010).

The monotonous work is outweighed by good working conditions and a higher than average salary. In addition, the favorable non-financial benefits may be attractive for young people because the work culture of service centers is oriented in many places to the Y-generation. Examples of such Y-generation-oriented benefits are: work in youthful teams (in most centers the average age is under 30 years), the work environment orientated towards young people (relaxation rooms, dining rooms, fitness rooms, telecommuting options) and opportunities for personal development (foreign language, foreign training).

\section{CONCLUSIONS}

The research shows that there is roughly a ten to fifteen-year history of shared service model regional practices, which emerged as a quasi-mature business services market, but apart from some university/college thesis work, case studies and market reports by international consulting firms, very few scientific studies have been conducted on shared services. The reason for this is mainly that the business services sector is relatively difficult to define in terms of a statistically-distinct area.

However, the subject is very interesting as it is one of the few sectors that could grow steadily during the years of economic crisis and significantly has changed the labor market or even office rental market in Central and Eastern Europe over the past fifteen years. But it is no coincidence that the large international consulting firms are interested in the subject, since there are more than one hundred service firms and tens of thousands of employees in this area. These centers are continuously developing and expanding organizationally, and make use of the international knowledge or even local market knowledge of international consulting firms. The employees working in the sector speak several languages and earn a better than average salary. Thus, the sector is of major economic importance, both in terms of taxes and the labor market.

In addition to tax revenues and jobs, of course, the world-class service technologies and processes have clear positive effects on the economies of the region. Therefore, the sector has significant policy emphasis, strong professional advocacy and representation.

In the service centers of the CEE region, a widening of service portfolios and an increase in the volume of services delivered can be observed. However, there is not only widening, but quality change as well. About half of the services delivered by regional shared service centers are higher value-added and according to experts, this tendency will continue in the following years. 
There are new organizational models for service center operations like CoE and GBS that could signify some kind of development stage for those centers who want to be state-of-the-art on this market. Virtualizatian is not a typical solution in CEE shared service centers. More shared service center is part of different hub-and-spoke solutions where in more cases the regional centers are in the hub role. I think this kind of work division will strengthen in the near future.

Looking towards the future, Central and Eastern Europe's share of the global market is expected to continue to grow at the expense of the Asia-Pacific markets due to diversification strategies.

\section{REFERENCES}

A.T. Kearney Research Studies. (2004). A.T. Kearney's Global Services Location Index (GSLI). Chicago: A.T. Kearney.

A.T. Kearney Research Studies. (2005). A.T. Kearney's Global Services Location Index (GSLI). Chicago: A.T. Kearney.

A.T. Kearney Research Studies. (2007). A.T. Kearney's Global Services Location Index (GSLI). Chicago: A.T. Kearney.

A.T. Kearney Research Studies. (2009). A.T. Kearney's Global Services Location Index (GSLI). Chicago: A.T. Kearney.

A.T. Kearney Research Studies. (2011). A.T. Kearney's Global Services Location Index (GSLI). Chicago: A.T. Kearney.

Bangemann, T. (2012). Where are we now? \& where are we going? Amsterdam: The Hackett Group.

Bencsik, E. (2012). Interjú a magyar shared service piacról. (intervewed by Róbert Marciniak, on September 6, 2012).

Bodnár, V. (2012). Interjú a magyar shared service piacról. (intervewed by Róbert Marciniak, on September 28, 2012).

Bőgel, G. (2009). Üzleti elvárások - Informatikai megoldások. Budapest: HVG Kiadó Zrt.

Bőgel, G. (2012). Interjú a magyar shared service piacról. (intervewed by Róbert Marciniak, on September 7, 2012).

Boulanger, P. (2011). Trends in Shared Services - Unlocking the Full Potential. Miami, FL: Accenture Global Shared Service Conference.

Chikán, A., \& Petényi, G. (2009). Nemzeti versenyképesség és versenyszabályozás: barátok vagy ellenségek? - fókuszban a multinacionális vállalatok. Budapest: $\mathrm{BCE}$, Versenyképesség Kutató Központ.

Cséfalvay, Z. (2005). Mit tanulhat Magyarország Indiától. Budapest: HVG Online, Retrieved on February 22, 2012, from http://img8.hvg.hu/velemeny/20050901csefalvay2

Csorján, B. (2013). Will Eastern Europe provide lower labour cost than China? Debrecen: SSC Debrecen Blog.

Dani, S., Dhingra, R., \& Singh, A. (2011). Global Offshore Captive Landscape and Trends. New York: Everest Group Research.

Dencik, J., \& Spee, R. (2013). Global Location Trends - 2013 annual report. Somers, NY: IBM Global Business Services. 
Dobák, E. (2009). Milyen egy szolgáltató központ ideális munkatársa?. Budapest: HR Portál, Retrieved on November 11, 2012, from http://www.hrportal.hu/c/milyen-egy-szolgaltatokoz pont-idealis-munkatarsa-20090928.html

Figyelő. (2009). Átmozgatás. Budapest: Figyelő Online, Retrieved on August 20, 2011, from http://www.figyelo.hu/cikkek/171179_atmozgatas

Foster, C., \& Funk, J. (2006). The Offshore Solutions Spectrum: Getting the Best Fit. Journal of Sourcing Leadership, 3(1), 1-3.

Futó, P., \& Klein, G. (2007). A Magyarországra kiszervezett üzleti folyamatok és üzleti szolgáltató központok. A befektetés-ösztönzés, a munkahelyteremtés és munkhahelymegörzés feltételeinek elemzése a szektorban. Budapest: Gazdasági és Közlekedési Minisztérium.

Gyimóthy, É. (2011). A szolgáltató szektor lehet hazánk kitörési pontja. Budapest: HR Portál, Retrieved on January 25, 2012 from http://www.hrportal.hu/hr/a-szolgaltato-szektorlehethazank-kitoresi-pontja-20111111.html

Hackett Group. (2012). Zero to Superhero. 13th Shared Service \& Outsourcing Week: Hackett Grop. Hegedűs-Varga, E. (2013). HITA szerepvállalása. Debrecen.

Henterné, Á.T. (2012). Interjú a magyar shared service piacról. (interviewed by Róbert Marciniak on July 12, 2012).

Hoffmann, Á. (2012). Interjú a magyar shared service piacról. (interviewed by Róbert Marciniak on July 11, 2012).

Hogan, S., Moller, P., \& Sondhi, S. (2013). 2013 Global Shared Services survey results. London: Deloitte Consulting LLP.

HR Portál. (2012a). A szolgáltató központok szívhatják fel a munkanélküli fiatalokat. Budapest: HR Portál, Retrieved on December 20, 2012 from http://www.hrportal.hu/c/aszolgaltatokoz pontok-szivhatjak-fel-a-munkanelkuli-fiatalokat-20121210.html

HR Portál. (2012b). Mennyit fizetnek a multik ügyféltámogató központjai?. Budapest: HR Portál, Retrieved on December 25, 2012 from http://www.hrportal.hu/hr/mennyit-fizetnekamultik-ugyfeltamogato-kozpontjai-20121105.html

HVG. (2013). Magyarország szolgáltatóközpont-nagyhatalom lesz? Budapest: HVG.

ITDH. (2006). Outsource tendenciák a világban és Magyarországon. Budapest: Gazdasági Elemző Osztály, ITD Hungary.

Juhász, N. (2013). Interjú a magyar shared service piacról. (interviewed by Róbert Marciniak on July 2).

Kertész, D. (2011). HR-es kihívások a szolgáltató szektorban. Budapest: HR Portál, Retrieved on May 10, 2013 from: http://www.hrportal.hu/hr/hr-es-kihivasok-a-szolgaltato-szektorban20111114.html.

Klein, G. (2008). Társadalmi nem a szervezetben - A magyarországi üzleti szolgáltató központok mikroszociológiai jelenségvilága. Budapest: Budapesti Corvinus Egyetem, Szakdolgozat.

Lhermitte, M., Gruz, G., \& Levine, M. (2010). Waking up to the new economy - Ernst \& Young's 2010 European attractiveness survey. Paris: Ernst\&Young.

Mártonffy, A. (2010). Fővárosközpontúak a szolgáltató központok. IT Business, 8(17), 60.

Mózsik, T. (2008). Újabb szolgáltató központ Budapesten, Computerworld. Retrieved on October 15, 2011 from http://computerworld.hu/ujabb-szolgaltatokozpont-nyilt-budapesten.html

Mózsik, T. (2008). Újabb szolgáltató központ Budapesten, Computerworld. Retrved on October 15, 2011, from http://computerworld.hu/ujabb-szolgaltatokozpont-nyilt-budapesten.html 
Nagy, B. (2010). Interjú Vass Tiborral az E.On kelet-európai szolgáltatási igazgatójával. Budapest: IT Business Online, Retrieved on October 22, 2011, from http://www.itbusiness.hu/Fooldal/ hetilap/vipstafeta/Vass_Tibor.html

Nagy, E. \& Tóth, É.M., (2004). Fluktuáció a call centerben. Partnering Magazin, (December), 29-31.

Németh, K. (2012). Interjú a magyar shared service piacról. (interviewed by Róbert Marciniak on July 18, 2012).

NFM. (2010). Digitális Magyarország 2010-2014. Budapest: Nemzeti Fejlesztési Minisztérium, vitairat.

Out, A.M. (2008). Deciding on a Type of Offshore Business Model. Amsterdam: University of Amsterdam.

Palfrader-Fraz, C., Grönke, K., \& Imgrund, M. (2012). Shared Service Center in Osteuropa - Ende oder Fortführung der bisherigen Ousourcing-Aktivitaten? Wien: Horváth \& Partner Management Consultant GmbH Wien.

Palócz, É., Hamar, J., Jutkusz, L., Hárs, Á., \& Bogó, R. (2004). Az üzleti szolgáltatások helyzete Magyarországon - a nemzetközi tendenciák és empirikus felmérések tükrében. Budapest: KOPINT-DATORG Konjunktúra-, Piackutató és Számítástechnikai Rt.

Pintér, M. (2012). Interjú a magyar shared service piacról. (interviewed by Róbert Marciniak on July 23, 2012).

Privátbankár. (2012). A szolgáltató központoknak ismét vonzó célpont lett Magyarország. Budapest: Privátbankár, Rtrvieved on May 12, 2012, from http://privatbankar.hu/ingatlan/ aszolgaltato-kozpontoknak-ismet-vonzo-lett-magyarorszag-245125

Reviczky, Z. (2012). 2020-ra 150 ezer diplomás fog hiányozni a magyar munkaerőpiacról. Budapest: Népszabadság Online, Retrieved on October 25, 2012, from http://nol.hu/gazdasag/2020ra_150_ezer_diplomas_fog_hianyozni_a_magyar_munkaeropiacrol

Rusz, Á. (2013). Szolgáltató központok: itthon is világszínvonalon. Budapest: Magyar Projektmenedzsment Szövetség, Retrvieved on August 2, 2013, from http://www.pmsz.hu/ pmi/szolgaltato-kozpontok-itthon-vilagszinvonalon

Sangani, R. (2011). Trends Trends Trends. Shared Services \& Outsourcing Network. Retrieved on April 15, 2012, from http://www.ssonetwork.com/governanace-structure-outsourcinghybri d-shared-services/10836-A

Sebök, O. (2004). Európa új üzleti térképe. Piac\&Profit, V(6), 12.

Sebök, O. (2006). Középről az élre. Piac\&Profit, 10(5), 56-58.

Spee, R. (2013). Facilitating Investments During Difficult Times - Findings from IBM's Global Location Trends Report. Brussels: IBM Plant Location International .

SSC Recruitment. (2010). Az átlagnál magasabb munkaerő mozgás okai. Budapest: Exact Solution Recruitment Agency. Retrvied on Novembver 20, 2011, from http://sscguide.hu/news.php ?extend.1

Steer, M.J. (2007). Where do we go from here: captive, outsourced or hybrid model?. FAO Today Magazine, 4(4).

Suhajda, A. (2012). Interjú a magyar shared service piacról. (interviewed by Róbert Marciniak on August 10, 2012).

Sutcliff, M. (2004). State of Shared Services and BPO. Dublin: Accenture - Fifth Annual Global Shared Service Conference. 
Sütő, M. (2008). Két nyelven beszélő tálentumokat keresnek a szolgáltató központok. Budapest: HR Portál. Retrvived on December 10, 2012, from http://www.hrportal.hu/hr/ketnyelvenbeszelo-talentumokat-keresnek-a-szolgaltato-kozpontok-20081003.html

Szabó, Z. (2013). Felnőttkorba ért az SSC-szektor Magyarországon. Budapest: HR Portál. Retrvieved on November 5, 2013, from http://www.hrportal.hu/hr/felnottkorba-ert-az-ssc-szektormagy arorszagon-20131029.html

Szilágyi, K. (2011). Hogyan müködhetnek hatékonyabban a szolgáltató központok. Budapest: HR Portál. Retrieved on January 1, 2012, from http://www.hrportal.hu/hr/hogyan-mukodhetnek hatekonyabban-a-szolgaltato-kozpontok-20111114.html

Takács, G. (2009). Állást ér a ritka nyelv ismerete. Budapest: HR Portál. Retrived on November 11, 2012, from http://www.hrportal.hu/c/allast-er-a-ritka-nyelv-ismerete-20090423.html

Thorniley, D. (2003). Shared Services - Moving into Central and Eastern Europe. London: The Economist, White Paper.

Turi, P. (2013). Interjú a magyar shared service piacról. (interviewed by Róbert Marciniak on June 8, 2012).

Valkár, T. (2013). Interjú a magyar shared service piacról. (interviewed by Róbert Marciniak on May 10, 2013).

van Hove, P. (2011). Shared Services Strategies of Increasingly Globally Integrated Enterprises. Brussel: IBM Plant Location International.

Venkataraman, R. (2013). SSOs - moving up the value chain. Outsource Magazine, Spring 2013(31), 20-22.

VG Online. (2012). Az átlagnál magasabb munkaerő mozgás okai. Budapest: Világgazdaság Online. Retrieved on November 11, 2011, from http://www.vg.hu/vallalatok/szolgaltatas/aszolgaltat o-kozpontok-a-magyar-munkaeropiac-remenysegei-382014

VG Online. (2012). Elhódithatjuk Indiától a szolgáltató központokat. Budapest: Világgazdaság.

Vida, G. (2012). Interjú a magyar shared service piacról. (interviewed by Róbert Marciniak on August 2, 2012).

Williams, L. (2005). Best Model Shared Services. HR Global Magazine, 3(1), 6-8.

\section{APPENDIX: List of semi-structured interview questions}

1. Why were the CEE countries so popular as shared service locations in the last decade? What were the reasons for market progress?

2. Is there any recession in the business service market nowadays? If so, what are the reasons for it? How does the global crisis influence the business service market?

3. How important are shared service centers as actors in the national economies of the CEE countries?

4. What about the competition among the countries in the CEE market? What are the strengths and weaknesses of certain countries?

5. What are the most important factors in location-choosing?

6. What about subsidy systems? Could they positively affect location-choosing?

7. How viable is the shared service model in the long run? What are the model's limitations? 
Author

\section{Róbert Marciniak}

University lecturer in the Institute of Management Science at the Faculty of Economics, University in Miskolc (Hungary).

\section{Correspondence to:}

Róbert Marciniak

University of Miskolc

Faculty of Economics

Institute of Management Science

H-3515 Miskolc-Egyetemvaros, A/4. 313, Hungary

marciniak.robert@uni-miskolc.hu 